\title{
Jump-Starting Urban Rat Research: Conspecific Pheromones Recruit Wild Rats into a Behavioral and Pathogen-Monitoring Assay
}

\author{
Michael H. Parsons ${ }^{1,2 *}$, Ronald J. Sarno ${ }^{2}$ and Michael A. Deutsch ${ }^{3}$ \\ ${ }^{1}$ Department of Medicine, Columbia University Medical Center, New York, NY, USA, ${ }^{2}$ Department of Biology, Hofstra \\ University, Hempstead, NY, USA, ${ }^{3}$ Medical Entomology, Arrow Exterminating Company, Lynbrook, NY, USA
}

OPEN ACCESS

Edited by:

G. Darrel Jenerette,

University of California, Riverside, USA

Reviewed by:

Iryna Dronova

University of California, Berkeley, USA

Loren B. Byrne,

Roger Williams University, USA

*Correspondence:

Michael H. Parsons

parsons.hmichael@gmail.com

Specialty section:

This article was submitted to

Urban Ecology,

a section of the journal

Frontiers in Ecology and Evolution

Received: 22 August 2015 Accepted: 09 December 2015 Published: 24 December 2015

Citation:

Parsons MH, Sarno RJ and Deutsch MA (2015) Jump-Starting Urban Rat Research: Conspecific Pheromones Recruit Wild Rats into a Behavioral and Pathogen-Monitoring Assay. Front. Ecol. Evol. 3:146. doi: 10.3389/fevo.2015.00146
Wild rats, Rattus spp, have adapted so well to urbanization that humans may be obligatory to their survival. Consequently, rats foul human food sources, predate threatened fauna and serve as reservoirs for disease, costing the US economy $\$ 19$ billion in losses year ${ }^{-1}$. Urban rat ecology however, remains vastly unexplored because these animals are cryptic, crepuscular, difficult to identify, and hazardous to handle. Additionally, the high-rise buildings that block satellite link-ups, underground sewers and subway tunnels, and rebar enforced concrete covered landscape make it difficult - if not impossible - to track urban animals using traditional radio telemetry. Consequently, there are few ecological studies with free-ranging urban rats. Therefore, we set out to monitor the behaviors and health of free-ranging rats in metropolitan New York. Recognizing that wild rats are attracted to live laboratory-reared conspecifics and that they are sensitive to pheromones, we used soiled rat bedding to repeatedly attract animals to a Remote Frequency Identification (RFID)- based antenna with camera-trap and load cell (scale) for collecting weights. We captured and micro-chipped 13 rats within 50,30 , and $10 \mathrm{~m}$ from our antenna and followed their movements. Seven of the eight animals released within $10 \mathrm{~m}$ of the antenna, visited the RFID antenna lure 398 times over 41 standardized days. Males (2.7 visits day ${ }^{-1}$ ) visited the antenna at the same frequency as females (2.7 visits day $\left.^{-1} ; P>0.5\right)$, and both sexes spent similar time dwelling at the pheromones $(M, 2.9 \pm$ $0.9 \mathrm{~s} ; F, 2.4 \pm 0.4 \mathrm{~s} ; P>0.05)$. The passive integrated transponder (PIT)-tag worked free on the lone individual that did not participate. Within our population, female activity peaked between 6 a.m. and 7 p.m., while males visited throughout the day. Our results demonstrate the potential to safely overcome the primary barriers that have impeded urban rat ecological studies. We used pheromone-based lures to attract micro-chipped rats, irrespective of sex or age-class, where their individual identities, behaviors and pathogen loads could be consistently recorded. We discuss the potential for similar assays to help address several longstanding knowledge gaps in the literature regarding pathogen monitoring over time and space, rat dispersal patterns, population parameters, and seasonal migrations through corridors.

Keywords: biological assay, semiochemicals, Rattus norvegicus, remote sensing, RFID, rodentology, urban ecology 


\section{INTRODUCTION}

Wild rats, Rattus spp, have adapted so well to human settlements that humans may be obligatory to their survival (Aplin et al., 2003). Due to their generalist foraging strategy and ability to adapt to novel environments, they have become synonymous with global urbanization, with rats commonly observed in public transportation, city parks, restaurants, and private dwellings. There are between 250 million and 1.4 billion rats in the United States, with the majority in urban centers where $80 \%$ of the human population resides (Pimentel et al., 2005). As rat populations increase, their importance as reservoirs for pathogens such as Salmonella (Hilton et al., 2002), Toxoplasma (Berdoy et al., 2000), Leptospira (Athanazio et al., 2008), Rikettsia, Bartonella, and Hanta (Firth et al., 2014) also rises. Furthermore, they foul food-stuffs, cause structural damage by gnawing on cables and vehicle wires and are suspected of instigating the majority of building fires' of unknown origin'. From an ecological perspective, rats have decimated native species of birds and reptiles by consuming eggs and live young (Jones et al., 2008). All together, they cause \$19 billion in losses to the US economy, with $\$ 1.3$ billion in New York City alone (Pimentel et al., 2005). The only means to control rats, are by regulating human habits and sanitation, or modifying rat behavior and physiology. Governing human behavior on a large scale, however, is tenuous, and there are few means to control rats based on their behavioral predispositions.

\section{Constraints to Urban Rat Research}

Urban rats are elusive, they burrow deep within dens, only appear briefly, and are usually moving rapidly when detected. Despite the near ubiquity of rats with human settlements, their behaviors and movements are largely unknown (Feng and Himsworth, 2014) and enormous knowledge gaps remain in the literature (Banks and Hughes, 2012). The challenges of working with urban rats have only been overshadowed by the problems of having such a limited data set on the behavior of an organism with the capacity to threaten our public health and economy to such a degree.

With direct observation not feasible, traditional monitoring techniques rely on remote sensing via radio-telemetry (Amlaner and Macdonald, 2013), Global Positioning Systems (GPS; Cagnacci et al., 2010), remote sensors for "bio-logging" healthrelated parameters (Ropert-Coudert and Wilson, 2005), and multimodal approaches such as GPS linked with wireless sensor networks (Handcock et al., 2009). Radio frequency identification (RFID) technology (Kim et al., 2010) sends electromagnetic fields to a passive microchip and words like a barcode for the identification of individual free-ranging animals. This approach is cheaper and less invasive than the other options, because it does not require fitting animals with collars. None of these techniques have been feasible in the built environment, however, because concrete, rebar and high-rise buildings block signal and satellite link-ups. Consequently, there are no viable research assays to monitor the behaviors, physiology, or changing pathogen loads of individual rats.
Furthermore, due to the capricious behavior and vector potential of rats, they are both difficult and risky to handle. Consequently, our contemporary understanding of urban-rat behavior is partly inferred from laboratory-reared animals However, domesticated rats have diverged behaviorally and genetically (Mitchell, 1976; Price and Huck, 1976), and using lab animals to understand wild urban rats, has been compared to using domesticated dogs as a model to understand wolf behavior. These challenges have contributed to an extensive gap in the literature since the research of the mid-20th century (Karli, 1956), and the seminal works on wild rat behavior are now over 60 years old (Cottam, 1948; Barnett and Spencer, 1951; Rzóska, 1953; Barnett, 1955, 1958, with the Davis et al., 1948) study on home range and territory now 67 years old. Feng and Himsworth (2014) and Banks and Hughes (2012) have recently identified a few of the essential gaps that require addressing in the wild rat literature. These include behavioral and ecological studies that address the natural causes of rat mortality, how rats interact with specific features of the built environment, and importantly, how rat ecology influences disease vector potential to humans (Feng and Himsworth, 2014).

The Vancouver Rat Project (Himsworth et al., 2014) has attempted to address many of the ecological and epidemiological gaps in the literature. There has been little momentum in the United States or Europe, however, to understand urban rat behavior and ecology. A recent special issue of the journal Vector-Borne and Zoonotic Diseases highlights the paucity of research. The issue was reserved for rodent-borne pathogens and their potential impact on public health and safety. Despite the widespread prevalence of zoonotic pathogens such as Rikettsia, Bartonella, and Hanta across urban areas in the US, and Firth et al.'s (2014) and Feng and Himsworth's (2014) open call to proactively monitor rat-related health risks, the special issue was limited to scientific contributions from Southeast Asia and Canada. With no known wild rat behavioral assays that work in urban contexts, the efficacy of monitoring pathogens, or creating deterrents and attractants is difficult, and prohibitively expensive, to estimate.

\section{Importance of Urban Rat Assays}

Finding appropriate means to research rats in the urban environment may yield a host of ecological and public-health related benefits. With $75 \%$ of all humans expected to live within urban environments in developed countries, it is essential we pilot new mechanisms to closely monitor the changing pathogen loads of urban animals. For instance, after surveying rats in New York City, Firth et al. (2014) discovered 18 previously unknown pathogens closely related to those that cause disease among humans. Similarly, Frye et al. (2015) learned that rats in New York were not only reservoirs for disease carrying organisms, but they also carried ectoparasites that vector additional pathogens. For these reasons, the authors in both studies called for the urgent complete characterization of the diversity and distribution of urban rodent pathogens. In both studies, however, researchers were unable to handle live rats and euthanized animals prior to the assays, thus no spatial or temporal changes in habitat or distribution were possible. Banks and Hughes (2012) reported 
similarly daunting news when reviewing the literature of Black rats (Rattus rattus) in Australia. They identified significant gaps in our understanding of the ecological role of rats in Australia, despite the well-known damage to native species, including seedling establishment, nest predation of endangered seabirds, and harboring of human pathogens. While the call for new research was cogently made, there were no recommended methodologies to undertake such a program of study.

Any urban research program will likely require the means to identify rats at the individual level, a potentially daunting task. In addition to the hazardous handling and difficulty of following chipped animals in the built environment, one of the principal challenges of observing rats within an assay depends on recruiting animals without gender, or age-related bias. Males and less-experienced juveniles are more likely to be trapped than females of reproductive age (O'Farrell et al., 1994; Firth et al., 2014). Furthermore, only the weakest or elderly animals may risk entering an assay, because the most fit and able animals may outcompete conspecifics for limited foods available elsewhere. Finally, it is important to limit the traps to species-specific baits, to avoid trapping other mammals. The most promising attractant for recruiting wild rats without bias to age, experience, or sex is the use of live laboratory rats as lures (Shapira et al., 2013a,b). Live animal lures are less likely to attract non-target species. The mode of operation ostensibly depends on social facilitation (Shapira, 2014). Animals of both sexes become less sensitive to predation or risk, when detecting a live conspecific. Presumably their contempt for intrusion (mate guarding and resource control) offsets any fear of predation, or neophobia. This approach to biological control is innovative and consistent. It is only limited by the time and costs necessary to find and deploy live lab rats in proximity to the target rodent populations throughout the city.

\section{Pheromones as a Recruitment Tool for Rats}

Human food-based lures have limited appeal to rats, as they habituate quickly to baits, and have site-specific food preferences that shadow the diets of nearby people. While effective, live animal lures are not realistic in an urban environment either. Rats are, however, quite sensitive to pheromones, either from predators (Apfelbach et al., 2015), or conspecifics (McGregor et al., 2002; Kumar et al., 2014). Intraspecific fighting is common among male rats, and pheromones may be the key to "unlock aggressive behavior" in rats toward other rats; males are actually more likely to fight over an estrous female than food resources (Feng and Himsworth, 2014). Hence, in a biological assay, male rat pheromones may be more likely to attract inquisitive or territorial males to investigate the scent, while female rat pheromones may be more likely to lure males seeking mates. It is unclear whether females will be attracted to the pheromones of either sex. Female mice (Mus musculus domesticus) have recently been shown to be attracted to male scent (Roberts et al., 2014). Male mice invest heavily in depositing an involatile protein (major urinary protein, MUP) called Darcin with their urine scent, which ostensibly transmits information to the female to assist mate choice. Like mice, male rats also secrete copious amounts of MUP, and neurons in the amydgala (posterodorsal medial section) of the female rat were shown to be activated by male MUPs (Kumar et al., 2014).

In addition to being attracted to scents, rats are finely attuned to using scents in order to make decisions about where and when to forage. Due to their small size and vulnerability to predation from a wider range of predators, scents are even more important regardless of whether they are emitted from a predator or a conspecific (Morrow et al., 2002). Importantly, rats were more likely to be repelled from cat dander collected from flea collars (a sign the animal is in close proximity), than a stronger scent that had aged (McGregor et al., 2002). The derivation of the scent is also important; scents from animal wastes (urine and feces) are more likely to advertise the past presence of an animal (Hegab et al., 2014), while dander or furs are more likely to advertise the current presence of an animal (McGregor et al., 2002). However, the scents from dander and fur are highly volatile from the oils in sebum, and quickly dissipate, leaving behind only the aged "skeleton" of the former scent. Accordingly, bedding from pooled scents of lab animals (dander, sebum, feces, and urine from males and females) may serve as a biological speciesspecific attractant because other species would be minimally interested.

When creating pheromone-based attractants or repellents for rats, a signal other than wastes is essential, one that signifies the animal is in the current location-right nowwhile controlling for the aging of the signal. This approach is accomplished by topping off the scent regularly before the scent's biological "meaning" changes (Apfelbach et al., 2015). Therefore, given the primary drawback of RFID approaches that require animals to "voluntarily" visit the antenna, we used pheromones, topped off weekly, from soiled rat bedding to pilot a new technique to allow the capture and monitoring of wild rats over time.

\section{Objectives}

Our objectives were to trial a novel method to overcome the two principal barriers associated with remote sensing of wild rats in an urban environment, animal handling/deployment of tracking devices and monitoring of those devices following release. To our knowledge, no one has ever RFID-tagged wild rats in a major metropolitan area, and few researchers have handled wild rats without first euthanizing them (Firth et al., 2014). Therefore, the manner in which we collected data is novel. We were specifically interested in the frequency of animal visits to the antenna, and whether animal weights could be regularly recorded. Individual weights would provide information on local demographics, and whether the same animals would repeatedly visit the antenna so that changes in weight and pathogen load could be recorded (Berdoy et al., 2000; Balla et al., 2014). Additionally, realizing that female rats are more difficult to trap than male rats (Firth et al., 2014), and that improved trapping of females is essential for the improved use of immuno-contraceptives, we were particularly interested in learning whether female rats could be lured to the RFID antenna (henceforth "antenna") using pheromones, and where their individual identities and behaviors could be captured on video. 


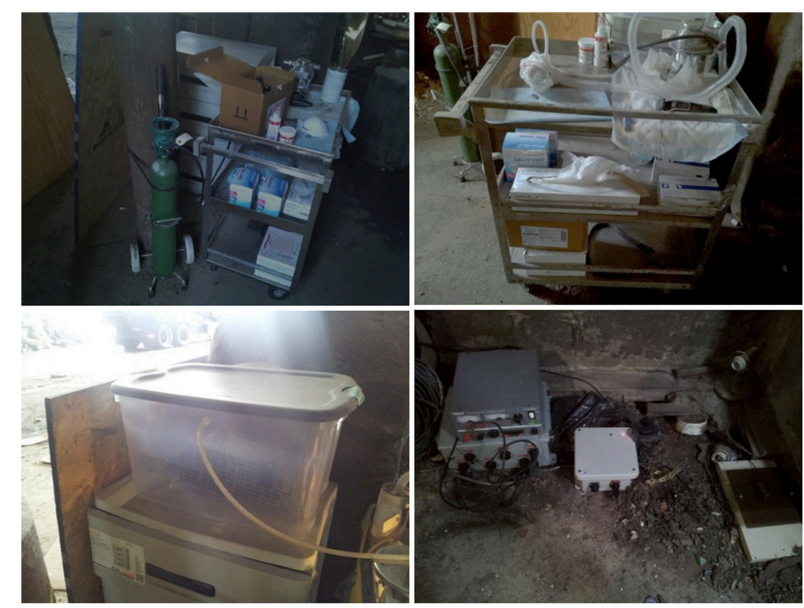

FIGURE 1 | Mobile anesthetic lab and outdoor RFID system for wild Norway rats, Rattus norvegicus, captured on Eastern Long Island and monitored from January 14-May 15.

\section{METHODS}

\section{Animal Handing and Implantation}

The capture and handling of wild rats is hazardous and time consuming. Therefore, we are providing detailed accounts on the process we used to safely and humanely subdue rats, while minimizing contact with, and discomfort for, the animals. Rats were trapped in Havahart $18 \times 5 \times 5$ humane animal traps (King and Scurr, 2013), baited with peanuts, and covered by a dark pillowcase or neoprene cover to minimize the startle response when picked up by humans. Home range and colony size for rats are both resource and density-dependent. Therefore, in lieu of having this information for our trial site (details of this site are withheld for privacy reasons) we arbitrarily placed traps in areas that were within 10, 20, and $50 \mathrm{~m}$ of the RFID antenna. Following capture, we utilized a field-based mobile laboratory (Figure 1) composed of a Midmark Matrx VIP 3000 calibrated isoflurane vaporizer with dual procedure circuit attached to a $61 \times 91 \mathrm{~cm}$ Tupperware container modified into an induction chamber with an oversized feline mask VetEquip (Pleasantville, Ca.). We set isoflurane to $5 \%$ with a flow rate of $2-3 \mathrm{ml} \mathrm{O}_{2} / \mathrm{min}$.

\section{Minimizing Risk of Pathogen Exposure and Discomfort for Animal}

Animals may awaken within seconds following anesthetic by isoflurane. Hence, following capture, at least two researchers donned personal protective equipment (PPE; masks, gauntlets). One researcher placed the cage with animal inside, directly into a $61 \times 91 \mathrm{~cm}$ modified induction chamber for up to $20 \mathrm{~min}$. until the animal showed signs of slowed movement. During this time, the second researcher monitored breathing of the animal, set remaining dials on the vaporizer and hoses, and prepared to place the mask over the animal within $3 \mathrm{~s}$ of its removal from the cage (Figure 2). To remove rats the first researcher lifted the cage up at a $45^{\circ}$ angle and released the trap door freeing the animal onto

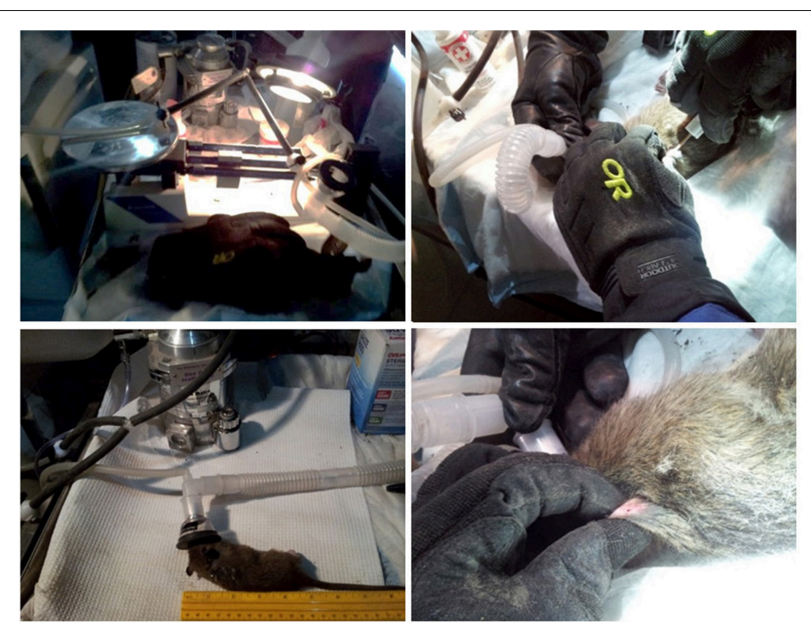

FIGURE 2 | Surgical table and implant procedure for wild Norway rats, Rattus norvegicus, captured on Eastern Long Island and monitored from January 14-May 15. the base on the chamber. The first researcher used the toe-pinch method to determine consciousness, lifted the animal out of the cage, and onto the surgical area.

The second researcher then placed the oversized mask over the animal and reset the isoflurane to $3 \%$ rate on $3 \% \mathrm{O}_{2}$ flow (Balla et al., 2014). We then recorded sex, weight, and body measurements. Body condition was noted on a progressive scale of 1-4, with 4 indicating no signs of porphyrin stains around the eyes, absence of mottled hair or bite marks, and vibrissae and guard hairs intact. We then placed the animal onto the table ventral side down, and shaved a $2 \times 2 \mathrm{~cm}$ section of hair (Figure 2) between shoulder blades without chaffing the animal. We prepped the shaved area with betadine and cotton swab in an inside out motion to sterilize. Pre-sterilized, lancet style Trovan ID-100US microchips $(12.5 \mathrm{~mm})$ were inserted below the skin at the nape of the neck, between the right and left scapula. We pinched the skin between fingers to form a tent and inserted the needle bevel up, eject chip from retractor, fingers in place to grasp chip on outside of skin (Figure 2). We removed the needle with a $180^{\circ}$ twist and checked for bleeding, used gauze, firm pressure and vet glue when necessary to seal wound. With mask still in place, animal still ventral side down, we took sharp surgical scissors and snipped $<2.5 \mathrm{~mm}$ from tail, added to a marked tube with DNA preservative. Firm pressure and Kwik Stop ${ }^{\circledR}$ styptic powder was used to cauterize the tail.

Following successful implantation, animals were returned from the mobile field laboratory to the site of capture and covered with cloth to prevent hypothermia. We recorded where animals went following recovery. Instead of ear-tagging animals, we determined recaptures by manually waving captured rats over the RFID antenna prior to anesthesia. All surgeries were performed under isoflurane anesthesia and all procedures were in accordance with the guidelines for ethical conduct in the care and use of nonhuman animals in research (Hofstra IACUC \#14/15-3). Due to high numbers of rats at the private 
field site, onsite regulations required baiting of rats with poison. Therefore, routine poisoning by Difinacoum went on continuously throughout the project, and rat mortality was expected to be high.

\section{Remote Sensing}

We used the SA-148, SQID customizable PIT-tag system (Seabird model) modified for this project by VANTRO systems, LLC. The unit was modified with a battery eliminator and powered by $240 \mathrm{~V}$ A/C mains. Data were captured by a data logger with a 2 GB memory capacity and USB connection. A load cell (scale; 38.6 ticks per g) was attached to the system-control unit. Data were extracted from the system-control unit through the use of Windows-based Hyperterminal software. The system had an operating range of $0-100^{\circ} \mathrm{F}$, and remained powered at all times, except otherwise noted. The extracted data were then processed using a macro-enabled spreadsheet template (Microsoft Excel 2000) that was developed specifically for the RFID data.

\section{Pheromones and Camera-Trap}

We used soiled rat bedding with sebum, dander, feces, and urine, collected regularly from a local pet shop, placed directly on the antenna to lure wild rats to the antenna. We maximized the freshness of the pheromone by storing in a cool, dark place under minimal head space in order to minimize the differential volatility of chemicals that advertise past or present state (Hegab et al., 2014). Importantly, we did not freeze the scent as this could change conformational state of carrier proteins important in scent dispersal. We mounted a Wildgame Innovations, Razor, 6.0-Megapixel Digital Trail Camera $2 \mathrm{~m}$ from the RFID antenna and aimed at the antenna.

\section{Data Collected and Statistical Analysis}

The data parsed from the RFID data logger included the transponder ID number, date, and time (hh:mm:ss:ms) an animal stepped on the scale, date and time the animal stepped off the scale, and weight (g). The data were then imported into SAS where the number of visits per day, and dwell time were calculated. Dwell time (seconds) was calculated as difference between the time the animal stepped on and off the scale. For instances when an animal stayed on the scale for only a fraction of a second, the dwell time was coded as $0 \mathrm{~s}$. Due to the high mortality rate of animals (under baiting regime), we standardized "days elapsed" by recoding the first day that the animal was RFID-tagged as day 1 and the monitoring period ceased on the final day activity. We performed repeated measures ANOVA to compare the number of visits per day, dwell time, and peak activity time between males and females using the PROC MIXED method in SAS.

\section{RESULTS}

A total of 13 animals were safely captured, tagged and released. Nine of the captured animals were male, 4 were female, and 2 were juveniles ( 1 female, 1 male). Seven of eight animals that were caught and released within $10 \mathrm{~m}$ of the antenna returned to the antenna at least once (Table 1). The RFID-tag worked free on the

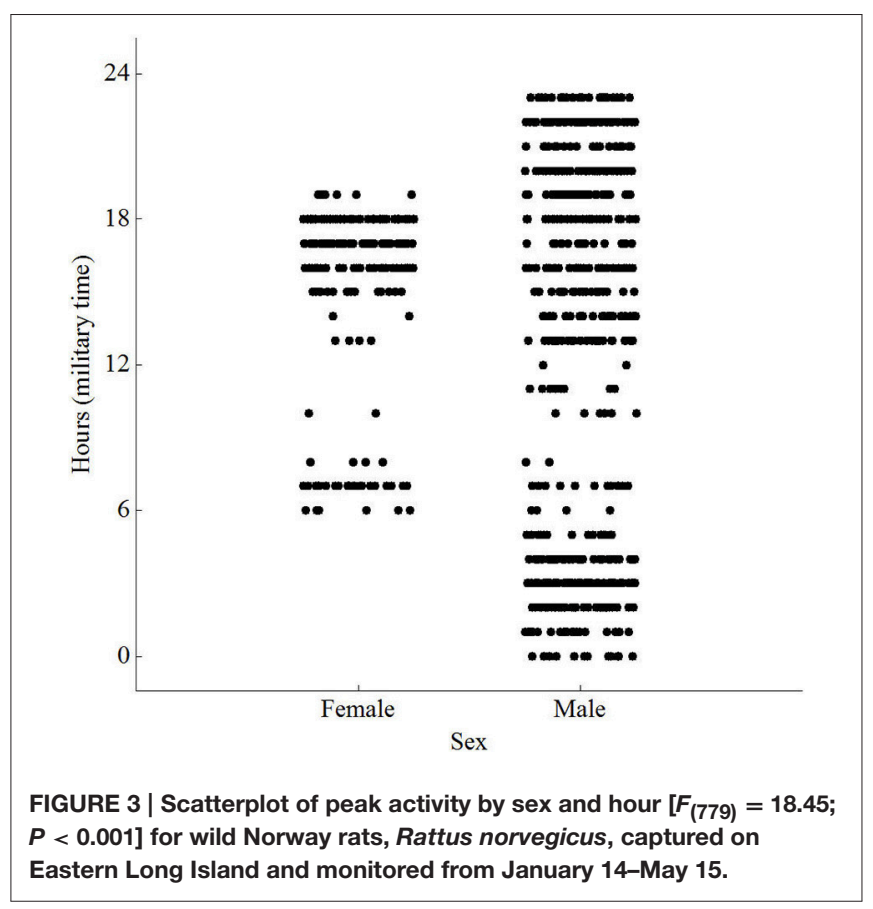

lone animal that did not participate. Additionally, four of these animals were captured in traps repeatedly (as many as 4 times). Overall, animals visited a total of 397 times (Table 2). The average number of visits per day by an individual was $2.6(\mathrm{SD}=4.8)$ with one individual visiting 39 times in 1 day. No animals captured $20 \mathrm{~m}$ or $50 \mathrm{~m}$ from the antenna returned to the antenna. Overall, the average dwell time across all individuals was $3.9 \mathrm{~s}(\mathrm{SD}=10.1)$ with one individual dwelling for a maximum of $121 \mathrm{~s}$. The lowest average dwell time per individual was $0.5 \mathrm{~s}$, while the maximum was $6.25 \mathrm{~s}$. The maximum number of days between first visit and last visit was 41 , with a minimum of 1 and an average of 18.9 $(\mathrm{SD}=16.1)$.

The animals visited different times during the day, with no preference for any single hour. However, females visited between 06:00 and 19:00, while males visited throughout the day and night (Figure 3). Both sexes were less active between 0900 and 1300. Video showed animals approaching, investigating and dwelling at the scent, accompanied by frenetic, jerky movements of the head. The video, however, was over-exposed, at times unclear, and therefore omitted from the analysis. Repeated measures ANOVA did not reveal any significant difference in dwell time at the antenna between males and females $\left[F_{(1,6)}=0.01, P=0.942\right.$; Table 1]. Similarly, there was no significant difference in number of visits per day between males and females $\left[F_{(1,6)}=0.69\right.$, $P=0.438]$. The average weight of animals recorded on the load cell differed by up to $90 \%$ from actual weights taken prior to release, with $0 \mathrm{~g}$ values being recorded for six of the animals.

\section{DISCUSSION}

We have taken the first step to address Frye et al. (2015), Feng and Himsworth (2014), Firth et al. (2014), and Banks and Hughes' (2012) calls to address the extensive gaps in urban rat ecology, 
TABLE 1 | Descriptive statistics for wild Norway rats, Rattus norvegicus, captured on Eastern Long Island and monitored from January 2014-May 2015.

\begin{tabular}{|c|c|c|c|c|c|c|}
\hline PIT-tag \# & $\begin{array}{c}\text { Sex/ } \\
\text { juvenile }\end{array}$ & $\begin{array}{c}\text { Weight } \\
\text { (g) }\end{array}$ & $\begin{array}{l}\text { Length } \\
\text { (mm) }\end{array}$ & $\begin{array}{c}\text { Condition } \\
\text { (1-4) }\end{array}$ & $\begin{array}{c}\text { Capture/release } \\
\text { point }(\mathbf{m})\end{array}$ & $\begin{array}{r}\text { Recruitment to } \\
\text { antenna }(\mathrm{Y} / \mathrm{N})\end{array}$ \\
\hline \multicolumn{7}{|c|}{ BY INDIVIDUAL } \\
\hline 4556 & $\mathrm{~F}$ & 250 & 19 & 4 & $<10$ & Y \\
\hline BD3F & $M$ & 350 & 21 & 4 & $<10$ & Y \\
\hline C166 & $M$ & 448 & 25 & 3 & $<10$ & Y \\
\hline $\mathrm{C} 2 \mathrm{~A} 6$ & $\mathrm{~F}$ & 179 & 18 & 3 & $>50$ & $\mathrm{~N}$ \\
\hline 03BB & $M$ & 423 & 25 & 3 & $>50$ & $\mathrm{~N}$ \\
\hline 9639 & $\mathrm{M}$ & 380 & 23 & 2 & $<10$ & Y \\
\hline 9DCA & M & 424 & 22 & 2 & $<10$ & Y \\
\hline B148 & $\mathrm{F}$ & 427 & 21 & 3 & $<10$ & $Y$ \\
\hline 7FAO & $\mathrm{M} / \mathrm{j}$ & 140 & 16 & 4 & $>30$ & $\mathrm{~N}$ \\
\hline $57 \mathrm{C6}$ & $M$ & 356 & 20 & 4 & $>30$ & $\mathrm{~N}$ \\
\hline 8768 & $\mathrm{~F} / \mathrm{j}$ & 87 & 12 & 4 & $<10$ & $\mathrm{~N}$ \\
\hline A06E & $\mathrm{M}$ & 468 & 22 & 1 & $>30$ & $\mathrm{~N}$ \\
\hline F002 & $M$ & 256 & 19 & 1 & $<10$ & Y \\
\hline \multicolumn{7}{|l|}{ BY SEX } \\
\hline Male & $9 / 1$ & 388 & 22 & & & 6 \\
\hline Female & $4 / 1$ & 285 & 19 & & & 2 \\
\hline
\end{tabular}

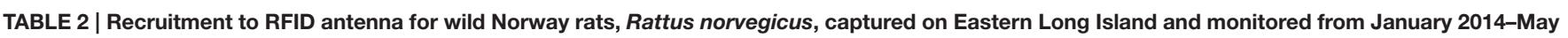
2015.

\begin{tabular}{|c|c|c|c|c|c|c|c|}
\hline Rat & $\begin{array}{c}\text { Total visits } \\
\text { visits }\end{array}$ & $\begin{array}{l}\text { Days visited/ } \\
\text { total days }\end{array}$ & $\begin{array}{c}\text { Proportion days } \\
\text { visited }\end{array}$ & $\begin{array}{l}\text { Average visits } \\
\text { day }\end{array}$ & $\begin{array}{l}\text { Total dwelling } \\
\text { time (sec) }\end{array}$ & $\begin{array}{l}\text { Average dwelling } \\
\text { time } \pm(\mathrm{sec})\end{array}$ & $t ; P$ \\
\hline \multicolumn{8}{|c|}{ BY INDIVIDUAL } \\
\hline 4556 & 101 & $20 / 41$ & 0.49 & 2.5 & 322 & 3.2 & \\
\hline BD3F & 27 & $9 / 32$ & 0.28 & 0.8 & 53 & 2.0 & \\
\hline C166 & 92 & $22 / 35$ & 0.63 & 2.6 & 144 & 1.6 & \\
\hline 9639 & 5 & $3 / 13$ & 0.23 & 0.4 & 10 & 2 & \\
\hline 9DCA & 2 & $1 / 1$ & 1 & 2 & 1 & 0.5 & \\
\hline B148 & 3 & $1 / 1$ & 1 & 3 & 7 & 2.3 & \\
\hline 7FAO & 18 & $4 / 5$ & 0.8 & 3.6 & 87 & 4.8 & \\
\hline F002 & 149 & $21 / 23$ & 0.91 & 6.5 & 925 & 6.25 & \\
\hline \multicolumn{8}{|c|}{ BY SEX } \\
\hline Male & & & 0.64 & 2.7 & & $2.9 \pm 0.9$ & $0.26 ; 0.609$ \\
\hline Female & & & - & 2.7 & & $2.8 \pm 0.4$ & \\
\hline
\end{tabular}

at a time when over half of the world's human population lives in urban areas. To do so, we have addressed the two primary barriers that have impeded the behavioral and ecological study of wild rats in metropolitan areas: pathogen exposure from aggressive animals and the ability to monitor the same individuals in the built urban environment. Seven of the eight animals that were RFID-tagged and released within $10 \mathrm{~m}$ of the antenna returned to the RFID-antenna had their presence recorded each visit, weights captured by load cell and behaviors captured on video. The lone animal that did not return was an $87 \mathrm{~g}$ female juvenile. In this individual, the microchip worked its way free.

We were not surprised that rats visited the RFID-antenna. First, live lab rats are very effective lures for wild rats (Shapira et al., 2013a,b; Shapira, 2014), and secondly, many rodents are attuned to making space:use decisions based on the scents of conspecifics (Roberts et al., 2014). We were surprised, however, with the consistent nature in which rats visited the assay. We arbitrarily considered 2 visits per week as a reasonable number of incidences to record the presence, time of visit, and periodic weight changes of all individuals, while 1 visit per month would have been sufficient to monitor changes in pathogen load of rats and their ectoparasites. Instead, animals of both sexes visited an average of almost 3 times per day, with two rats ( 1 male, 1 female) visiting every single day.

We were equally surprised that 4 of the rats were trapped repeatedly. We suspected rats would become more suspicious of entering a trap after having previously been captured. We have no data to compare our outcomes to. It is reasonable however, 
to suspect that the recent voids of conspecific pheromones were evocative enough to override fear of recapture. The repeated captures allowed us to take additional tissue, and any changes in ectoparasite load, to monitor changes in pathogen load.

The high frequency of female visits-and corresponding dwell times-were noteworthy. Males are antagonistic and would naturally be excited with the nearby scent of intruder conspecifics (Feng and Himsworth, 2014). Females, on the other hand may be particularly interested in male pheromones, specifically the MUP, Darcin (Kumar et al., 2014). An improvement in trapping females, may improve the administration of single-dose injectable vaccines for sterilizing females (Massei and Cowan, 2014) - as females are widely known to be less attracted to traps as compared to males.

We are unsure as to why males among our population visited throughout the evening and females restricted their visits to early morning and late afternoon. This time disparity may be expected however, because females are sometimes both risk-averse and subordinate to feeding times by males (Feng and Himsworth, 2014). This information, undoubtedly varies by site, but if determined at a local scale, has relevance for rat contraceptive control in urban environments. This is particularly important where the aim is to improve the number of adult females attracted into traps.

Animals of both sexes become less sensitive to predation or fear, when detecting a live conspecific. Ostensibly, their contempt for intrusion (mate guarding and resource control) offsets any fear of predation, or neophobia, and thus they are more easily trapped. It is highly unlikely that an animal will habituate to pheromones, as ignoring cues by potentially lethal conspecifics would have serious consequences.

While total rat population size and home range are density and resource-dependent, an approximation of home range is often important for management regimes that administer dose-dependent rodenticides or exclusion devices. Additionally, knowledge of average home range size is essential in order to understand the ecological and behavioral interpretations for space:use patterns (Spencer et al., 1990). All animals tagged and released within $10 \mathrm{~m}$ of the antenna, returned to the antenna, whereas no animals released at distances $>10 \mathrm{~m}$, returned at any time. This may suggest that the home range of our population was $<10 \mathrm{~m}$. Animals captured beyond this point were likely part of other colonies, and thus traversed and/or defended other territories.

Due to the smaller sample size, however, we reserve judgment on how to interpret the lack of visitations from animals captured $20 \mathrm{~m}$ or farther from the antenna. This may be due to the high mortality of animals that were actively poisoned (Difenacoum) throughout the duration of the project, or it could shed light on the relatively-small average size territory that this population ranged within. If accurate, the range of these urban rats were $<10 \%$ of the home range of Merriam's kangaroo rat (Dipodomys merriami, Jones, 1989) and $<15 \%$ of the homerange reported from 11 radio-collared ship rats (Rattus rattus) in Northern New Zealand (Dowding and Murphy, 1994). Again, we note the limitations of our study, and highlight the importance of determining home range size at the local scale.
Even with overexposed images of the video camera we were able to decipher individual movements around the scents, and this was helpful in understanding when multiple animals had stepped onto the load cell at the same time. Incidentally, the weight values recorded by the load cell were not consistent with our pre-recorded weight values. We believe the inconsistency can be attributed to two correctable factors. Animals occasionally leaned, but did not stand, directly onto the load cell, and thus partial weights were recorded. This may be corrected through the design of a larger surface area. Additionally, multiple animals (including non-chipped) were sometimes on the scale at a single interval. In these instances, a larger value was recorded.

\section{Broader Implications of New Urban Rat Research}

Fresh, pooled, soiled bedding including dander, sebum, feces, and urine from live laboratory rats attracts male and female adult and juvenile rats to the RFID antenna, where their individual behaviors and weights can be monitored over time. Food-based rat attractants are limited due to significant bias in gender, and age class. Therefore, this approach offers a mechanism to remove age and gender bias, and improve the efficacy of attracting rats for removal or injection of females for injectable contraceptives (Liu et al., 2013).

A wealth of ecological information may be extracted from new urban rat assays in an urban context. For instance, in our study population, we learned when males and females were most active (Figure S1), at specific intervals during the day, week, and month. RFID antennas may be set strategically to record the movements of animals across habitats, while placing antennas at either end of a burrow system may enable a standard BACI (before-after-control-impact) design so that researchers can trial and compare the efficacy of attractants and deterrents among natural populations. This design is sufficiently robust because individual responsiveness can be quantified by microchip and video (Figure S2).

Additionally, new urban rat research should seek to address rat dispersal patterns and movements through corridors, and statistically robust estimates of local population size. Additionally, despite the large human population that rats shadow, we have only scant information about the specific disease organisms that individual rats harbor (Frye et al., 2015), how these organisms are vectored throughout the city, or how the specific pathogen load changes over time. We hope the methods presented in this paper can be used-or modified-to help inspire new understandings of the behavior and ecology of urban rats.

\section{AUTHOR CONTRIBUTIONS}

MP co-conceived the project and wrote the manuscript. RS coconceived the project and edited the manuscript. MD helped carry out the field work, and helped modify the design, while editing the manuscript. 


\section{FUNDING}

This project was self-funded by the three authors and relied on in-kind donations from Vantro Systems, Inc. and Arrow Pest Control (MD's time).

\section{ACKNOWLEDGMENTS}

We thank Wayne Culberth and Art Cameron of VANTRO Systems, LLC for the design, modifications and support for the RFID system. Urshuula Dulakia and Beverly Shelton of the Institute of Comparative Medicine (ICM) at Columbia University provided training on rodent handling and surgical procedures. Cadhla Firth of Commonwealth Scientific Industry and Research Organization (CSIRO- Australia) provided logistic support. Robert Corrigan of the New York City Department Mental Health and Hygiene (DOHMH) provided helpful advice throughout the project. Bob Wiemer (Arrow Pest Management) provided permissions for research collaboration. Matt Frye and Jody Gangloff-Kaufmann of Cornell University

\section{REFERENCES}

Amlaner, C. J., and Macdonald, D. W. (2013). A Handbook on Biotelemetry and Radio Tracking: Proceedings of an International Conference on Telemetry and Radio Tracking in Biology and Medicine. Oxford: Elsevier.

Apfelbach, R., Parsons, M. H., Soini, H. A., and Novotny, M. V. (2015). Are single odorous components of a predator sufficient to elicit defensive behaviors in prey species? Front. Neurosci. 9:263. doi: 10.3389/fnins. 2015.00263

Aplin, K. P., Chesser, T., and Have, J. T. (2003). Evolutionary biology of the genus Rattus: profile of an archetypal rodent pest. Aciar Monogr. Ser. 96, 487-498. Available online at: http://aciar.gov.au/files/node/451/mn96rats_ mice_and_people_rodent_biology_and_mana_29893.pdf\#page $=476$

Athanazio, D. A., Silva, E. F., Santos, C. S., Rocha, G. M., Vannier-Santos, M. A., McBride, A. J., et al. (2008). Rattus norvegicus as a model for persistent renal colonization by pathogenic Leptospira interrogans. Acta Trop. 105, 176-180. doi: 10.1016/j.actatropica.2007.10.012

Balla, D. Z., Schwarz, S., Wiesner, H. M., Hennige, A. M., and Pohmann, R. (2014). Monitoring the stress-level of rats with different types of anesthesia: A tailartery cannulation protocol. J. Pharmacol. Toxicol. Methods 70, 35-39. doi: 10.1016/j.vascn.2014.03.003

Banks, P. B., and Hughes, N. K. (2012). A review of the evidence for potential impacts of black rats (Rattus rattus) on wildlife and humans in Australia. Wildl. Res. 39, 78-88. doi: 10.1071/WR11086

Barnett, S. A. (1955). Competition among wild rats. Nature 175, 126-127. doi: $10.1038 / 175126 \mathrm{~b} 0$

Barnett, S. A. (1958). An analysis of social behaviour in wild rats. Proc. Zool. Soc. Lond. 130, 107-152. doi: 10.1111/j.1096-3642.1958.tb00565.x

Barnett, S. A., and Spencer, M. M. (1951). Feeding, social behaviour and interspecific competition in wild rats. Behaviour 3, 229-242.

Berdoy, M., Webster, J. P., and Macdonald, D. (2000). Fatal attraction in rats infected with Toxoplasma gondii. Proc. R. Soc. Lond. B Biol. Sci. 267, 1591-1594. doi: $10.1098 /$ rspb.2000.1182

Cagnacci, F., Boitani, L., Powell, R. A., and Boyce, M. S. (2010). Animal ecology meets GPS-based radiotelemetry: a perfect storm of opportunities and challenges. Philos. Trans. R. Soc. B Biol. Sci. 365, 2157-2162. doi: 10.1098/rstb.2010.0107

Cottam, C. (1948). Aquatic habits of the Norway rat. J. Mammal. 29, 299-299. doi: 10.1093/jmammal/29.3.299

Davis, D. E., Emlen, J. T., and Stokes, A. W. (1948). Studies on home range in the brown rat. J. Mammal. 29, 207-225. doi: 10.2307/1375387
Cooperative Extension provided helpful advice. We thank Donald Edmondson and the Center for Behavioral and Cardiovascular Health $(\mathrm{CBCH})$ at Columbia University for their support. We also thank Lawrence Levy and the Center for Suburban Sustainability at Hofstra University for their helpful support throughout the project.

\section{SUPPLEMENTARY MATERIAL}

The Supplementary Material for this article can be found online at: http://journal.frontiersin.org/article/10.3389/fevo. 2015.00146

Figure S1 | Density plot of recruitment by hour to RFID antenna for wild Norway rats, Rattus norvegicus, captured on Eastern Long Island and monitored from January 14-May 15. Each point represents an individual visit.

Figure S2 | Potential experimental design demonstrating the utility of using RFID technology with wild rodent populations to determine the efficacy of repellents or attractants for up to 5 colonies of rats, separated by at least $100 \mathrm{~m}$. Filled circle represents main colony entrance open circles represents bolt (escape) opening.

Dowding, J. E., and Murphy, E. C. (1994). Ecology of ship rats (Rattus rattus) in a kauri (Agathis australis) forest in Northland, New Zealand. N. Z. J. Ecol. 18, 19-27.

Feng, A. Y., and Himsworth, C. G. (2014). The secret life of the city rat: a review of the ecology of urban Norway and black rats (Rattus norvegicus and Rattus rattus). Urban Ecosyst. 17, 149-162. doi: 10.1007/s11252-0130305-4

Firth, C., Bhat, M., Firth, M. A., Williams, S. H., Frye, M. J., Simmonds, P., et al. (2014). Detection of zoonotic pathogens and characterization of novel viruses carried by commensal Rattus norvegicus in New York City. MBio 5, e01933-e01914. doi: 10.1128/mBio.01933-14

Frye, M., Firth, C., Bhat, M., Firth, M., Che, X., Lee, D., et al. (2015). Preliminary survey of ectoparasites and associated pathogens from Norway rats in New York City. J. Med. Entomol. 92, 253-259. doi: 10.1093/jme/tjv014

Handcock, R. N., Swain, D. L., Bishop-Hurley, G. J., Patison, K. P., Wark, T., Valencia, P., et al. (2009). Monitoring animal behaviour and environmental interactions using wireless sensor networks, GPS collars and satellite remote sensing. Sensors 9, 3586-3603.

Hegab, I. M., Jin, Y., Ye, M., Wang, A., Yin, B., Yang, S., et al. (2014). Defensive responses of Brandt's voles (Lasiopodomys brandtii) to stored cat feces. Physiol. Behav. 123, 193-199. doi: 10.1016/j.physbeh.2013.10.030

Hilton, A. C., Willis, R. J., and Hickie, S. J. (2002). Isolation of Salmonella from urban wild brown rats (Rattus norvegicus) in the West Midlands, UK. Int. J. Environ. Health Res. 12, 163-168. doi: 10.1080/09603120220129328

Himsworth, C. G., Parsons, K. L., Feng, A. Y., Kerr, T., Jardine, C. M., and Patrick, D. M. (2014). A mixed methods approach to exploring the relationship between Norway rat (Rattus norvegicus) abundance and features of the urban environment in an inner-city neighborhood of Vancouver, Canada. PLoS ONE 9:e97776. doi: 10.1371/journal.pone.0097776

Jones, H. P., Tershy, B. R., Zavaleta, E. S., Croll, D. A., Keitt, B. S., Finkelstein, M. E., et al. (2008). Severity of the effects of invasive rats on seabirds: a global review. Conserv. Biol. 22, 16-26. doi: 10.1111/j.1523-1739.2007.00859.x

Jones, W. T. (1989). Dispersal distance and the range of nightly movements in Merriam's kangaroo rats. J. Mammal. 70, 27-34. doi: 10.2307/1381666

Karli, P. (1956). The Norway rat's killing response to the white mouse: an experimental analysis. Behaviour 10, 81-103. doi: 10.1163/156853956X00110

Kim, S.-H., Kim, D.-H., and Park, H.-D. (2010). “Animal situation tracking service using RFID, GPS, and sensors," in 2010 Second IEEE International Conference on Computer and Network Technology (ICCNT) (Bangkok), 153-156.

King, C., and Scurr, D. (2013). Efficacy of a community-led rat control programme at Lake Taupo, New Zealand. Conserv. Evid. 10, 85-88. 
Kumar, V., Vasudevan, A., Soh, L. J. T., Le Min, C., Vyas, A., Zewail-Foote, M., et al. (2014). Sexual attractiveness in male rats is associated with greater concentration of major urinary proteins. Biol. Reprod. 91:150. doi: 10.1095/biolreprod.114.117903

Liu, Q., Qin, J., Chen, Q., Wang, D., and Shi, D. (2013). Fertility control of Rattus nitidus using quinestrol: effects on reproductive organs and social behavior. Integr. Zool. 8, 9-17. doi: 10.1111/j.1749-4877.2012.00296.x

Massei, G., and Cowan, D. (2014). Fertility control to mitigate human-wildlife conflicts: a review. Wildl. Res. 41, 1-21. doi: 10.1071/WR13141

McGregor, I. S., Schrama, L., Ambermoon, P., and Dielenberg, R. A. (2002). Not all 'predator odours' are equal: cat odour but not 2, 4, 5 trimethylthiazoline (TMT; fox odour) elicits specific defensive behaviours in rats. Behav. Brain Res. 129, 1-16. doi: 10.1016/S0166-4328(01)00324-2

Mitchell, D. (1976). Experiments on neophobia in wild and laboratory rats: a reevaluation. J. Comp. Physiol. Psychol. 90, 190. doi: 10.1037/h0077196

Morrow, B. A., Elsworth, J. D., and Roth, R. H. (2002). Fear-like biochemical and behavioral responses in rats to the predator odor, TMT, are dependent on the exposure environment. Synapse 46, 11-18. doi: 10.1002/syn. 10109

O’Farrell, M. J., Clark, W. A., Emmerson, F., Juarez, S. M., Kay, F. R., O’Farrell, T. M., et al. (1994). Use of a mesh live trap for small mammals: are results from Sherman live traps deceptive? J. Mammal. 75, 692-699.

Pimentel, D., Zuniga, R., and Morrison, D. (2005). Update on the environmental and economic costs associated with alien-invasive species in the United States. Ecol. Econ. 52, 273-288. doi: 10.1016/j.ecolecon.2004. 10.002

Price, E. O., and Huck, U. W. (1976). Open-field behavior of wild and domestic Norway rats. Anim. Learn. Behav. 4, 125-130. doi: 10.3758/ BF03214022

Roberts, S. A., Davidson, A. J., Beynon, R. J., and Hurst, J. L. (2014). Female attraction to male scent and associative learning: the house mouse as a mammalian model. Anim. Behav. 97, 313-321. doi: 10.1016/j.anbehav.2014 08.010

Ropert-Coudert, Y., and Wilson, R. P. (2005). Trends and perspectives in animalattached remote sensing. Front. Ecol. Environ. 3, 437-444. doi: 10.1890/15409295(2005)003[0437:TAPIAR]2.0.CO;2

Rzóska, J. (1953). Bait shyness, a study in rat behaviour. Br. J. Anim. Behav. 1, 128-135. doi: 10.1016/S0950-5601(53)80011-0

Shapira, I. (2014). Using Social Attraction to Enhance Trappability of Invasive Norway Rats (Rattus norvegicus). DOC Research and Development Series 342. Wellington: Department of Conservation.

Shapira, I., Shanas, U., Raubenheimer, D., and Brunton, D. H. (2013a). Laboratory rats as trap lures for invasive Norway rats: field trial and recommendations. $N$. Z. J. Ecol. 37, 240-245.

Shapira, I., Shanas, U., Raubenheimer, D., Knapp, C., Alberts, S., and Brunton, D. (2013b). Laboratory rats as conspecific biocontrol agents for invasive Norway rats R. norvegicus. Biol. Control 66, 83-91. doi: 10.1016/j.biocontrol. 2013.04.003

Spencer, S. R., Cameron, G. N., and Swihart, R. K. (1990). Operationally defining home range: temporal dependence exhibited by hispid cotton rats. Ecology 71, 1817-1822. doi: 10.2307/1937590

Conflict of Interest Statement: The authors declare that the research was conducted in the absence of any commercial or financial relationships that could be construed as a potential conflict of interest.

Copyright (c) 2015 Parsons, Sarno and Deutsch. This is an open-access article distributed under the terms of the Creative Commons Attribution License (CC BY). The use, distribution or reproduction in other forums is permitted, provided the original author(s) or licensor are credited and that the original publication in this journal is cited, in accordance with accepted academic practice. No use, distribution or reproduction is permitted which does not comply with these terms. 